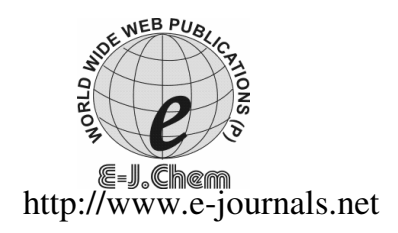

ISSN: 0973-4945; CODEN ECJHAO

E-Journal of Chemistry

2010, 7(3), 856-860

\title{
Development of Rapid UV Spectrophotometric Method for the Estimation of Efavirenz in Formulations
}

\author{
Y.ANAND KUMAR* and N.RAMA RAO \\ *Department of Pharmaceutics, V.L.College of Pharmacy, Raichur-584103, India. \\ Chalapathi Institute of Pharmaceutical Sciences, Lam, Guntur, India. \\ neeru241586@yahoo.co.in
}

Received 31 July 2009, Accepted 20 October 2009

\begin{abstract}
Simple, sensitive, accurate, precise and rapid ultraviolet (UV) spectrophotometric method was developed for the estimation of efavirenz in pure form, its formulations and stability samples. For the estimation of efavirenz, solvent system employed was $1 \% \mathrm{w} / \mathrm{v}$ sodium lauryl sulphate (SLS) and wavelength of detection $\left(\lambda_{\mathrm{det}}\right)$ was $247 \mathrm{~nm}$. The developed method was used to estimate the total drug content in two commercially available oral formulations of efavirenz and recovery studies were also carried out. Sample recovery in both the formulations using the above method was in good agreement with their respective labeled claims, thus suggesting the validity of the method and non-interference of formulation excipients in the estimation. The developed method was found to be stability specific and were validated as per ICH guidelines-2005, USP-2000 and statistical methods.
\end{abstract}

Keywords: Spectrophotometric determination, Sodium lauryl sulphate, Efavirenz

\section{Introduction}

Efavirenz belongs to the class of non-nucleoside reverse transcriptase inhibitors and is indicated in the treatment of HIV infection ${ }^{1-4}$. Efavirenz is chemically known as $(4 S)$-6-chloro-4-(2cyclopropylethynyl)-4-(trifluoromethyl)-2,4-dihydro-1H-3,1-benzoxazin-2-one and molecular weight is 315.7 . It is white to slightly pink powder, practically insoluble in water and freely soluble in methanol. It should be kept in a well closed container, protected from light.

Literature survey reveals that only HPLC methods are available for the estimation of efavirenz alone, in combination with other drugs, in its dosage form and in plasma ${ }^{5-10}$ however, no UV spectrophotometric method was found in literature. The present investigation has been undertaken to develop simple UV spectrophotometric method for the estimation of efavirenz in pure form and its formulations. 


\section{Experimental}

A Hitachi-U2000 spectrophotometer with a pair of matched quartz cells was to measure absorbance of the resulting solutions. Efavirenz was gifted by Strides Pharma. All the other reagents used were of analytical grade.

Preparation of standard curve

A $100 \mu \mathrm{g} / \mathrm{mL}$ stock solution of efavirenz was prepared in 1\%w/v SLS by first dissolving $10 \mathrm{mg}$ of the drug in $10 \mathrm{~mL}$ of methanol and then, made up to the final volume with $1 \% \mathrm{w} / \mathrm{v}$ SLS.

The $\lambda_{\max }$ of efavirenz was determined by scanning suitable dilutions with high correlation coeffiecient. From the stock solution, various standard dilutions were made to obtain solutions of $1,2,3,4$ and $5 \mu \mathrm{g} / \mathrm{mL}$. Their respective absorbance values were measured at fixed $\lambda_{\max }$ with parameter set at $0.5 \mathrm{~nm}$ for bandwidth as well as data pitch. Average absorbance values, standard deviation and \% coefficient of variance at each concentration were calculated. One way ANOVA test for linearity was carried out by picking five sets of calibration curves on random basis.

\section{Sample preparation (Bulk drug)}

Efavirenz $50 \mathrm{mg}$ was accurately weighed and taken into $100 \mathrm{~mL}$ volumetric flask containing $10 \mathrm{~mL}$ of methanol and further it was made upto $100 \mathrm{~mL}$ with $1.5 \% \mathrm{w} / \mathrm{v}$ sodium lauryl sulphate solution. This solution was further serially diluted with $1.5 \% \mathrm{w} / \mathrm{v}$ sodium lauryl sulphate solution to get $10,20,40,50,100 \mu \mathrm{g} / \mathrm{mL}$ solution. The efavirenz content was further determined by measuring the absorbance at $247 \mathrm{~nm}$.

Sample preparation (Dosage forms)

Twenty tablets were weighed and powdered; the powder equivalent to $50 \mathrm{mg}$ of efavirenz was weighed accurately and taken in $100 \mathrm{~mL}$ volumetric flask containing $50 \mathrm{~mL}$ of methanol. The contents were shaken well for 30 minutes and made upto the volume $100 \mathrm{~mL}$ with methanol. This solution was further suitably diluted with $1.5 \% \mathrm{w} / \mathrm{v}$ sodium lauryl sulphate solution and determined the efavirenz content by measuring the absorbance at $247 \mathrm{~nm}$.

\section{Recovery experiments}

To keep an additional check on the accuracy of the developed method and to study the interference of formulation additives, analytical recovery experiments were performed by adding known amount of pure drug to the previously analyzed pharmaceutical preparation and analyzed by the developed method. The concentration levels used were $10 \mu \mathrm{g} / \mathrm{mL}$.

\section{Results and Discussion}

\section{Method development}

To develop accurate, precise and sensitive UV spectrophotometric method for efavirenz, various solvent systems such as water, methanol etc. were tried alone and in combinations or in the presence of surfactants at different propotions. The final decision of using $1 \% \mathrm{w} / \mathrm{v}$ SLS in water was based on sensitivity, minimal interference, ease of preparartion, suitability for drug content estimation, stability, analysis time and cost. The $\lambda_{\max }$ for efavirenz in $1 \% \mathrm{w} / \mathrm{v}$ SLS (Figure 1) showed linear relationship (with correlation coefficient of 0.9988 ) in the concentration range of $1-5 \mu \mathrm{g} / \mathrm{mL}$ (Table $1 \& 2$ ).

\section{Sample solution stability studies}

Overlay scans obtained at zero time, 12,24 , and $48 \mathrm{~h}$ revealed no degradation upto $48 \mathrm{~h}$,in the selected solvent at controlled $\left(25 \pm 2^{\circ} \mathrm{C} ; 65 \pm 5 \% \mathrm{RH}\right)$ and accelerated $\left(40 \pm 2^{\circ} \mathrm{C} ; 75 \pm 5 \% \mathrm{RH}\right)$. Drug was stable for more than 48 hours, thus there can be time between collection of the sample and analysis of the same. 


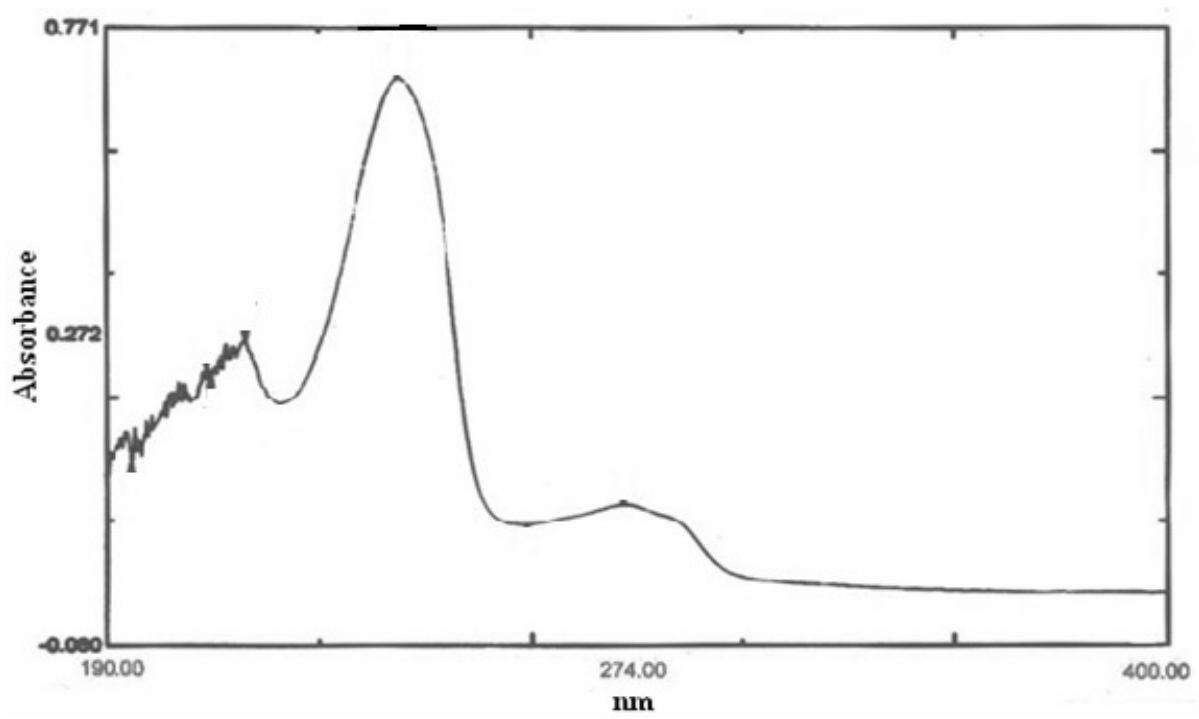

Figure 1. Spectra of $5 \mu \mathrm{g} / \mathrm{mL}$ solution of efavirenz in $1 \% \mathrm{w} / \mathrm{v}$ sodium lauryl sulphate.

Table 1. Calibration curve points of the proposed method for the estimation of efavirenz.

\begin{tabular}{lc}
\hline \multicolumn{1}{c}{ Parameters } & Values \\
\hline Absorption maxima, $\mathrm{nm}$ & 247 \\
Beer's law limit, $\mu \mathrm{g} / \mathrm{mL}$ & $1-20$ \\
Molar absorptivity, $1 \mathrm{~mole} \mathrm{-}^{-1} / \mathrm{cm}^{-1}$ & $2.21 \times 10^{-4}$ \\
Coefficient of correlation & 0.9998 \\
Regression equation*A & \\
Slope(b) & $0.05306 \pm 0.0004014$ \\
Intercept(a) & $0.0005238 \pm 0.001215$ \\
1/slope & -18.85 \\
Correlation coefficient(f) & 0.9999 \\
\hline
\end{tabular}

Table 2. Results of least square regression analysis of UV methods for the estimation of efavirenz.

\begin{tabular}{ccc}
\hline Concentration, $\mu \mathrm{g} / \mathrm{mL}$ & Mean $\pm \mathrm{SD}(\mathrm{n}=6)$ & $\mathrm{CV}(\%)$ \\
\hline 1 & $0.055 \pm 0.00634$ & 1.20 \\
2 & $0.107 \pm 0.00624$ & 1.43 \\
3 & $0.157 \pm 0.00610$ & 1.58 \\
4 & $0.214 \pm 0.00650$ & 1.62 \\
5 & $0.266 \pm 0.00818$ & 1.71 \\
\hline
\end{tabular}

\section{Recovery studies}

The method developed for the estimation of efavirenz in bulk and in its dosage forms was found to be simple, accurate, economical and rapid. Table 3-5 clearly indicates the drug content was uniform ranging from 98 to $99.55 \%$ and SD, CV values were found to be satisfactorily low. Recovery studies were also carried out and found to be 98.89 to $98.89 \%$ for the both batches of tablets. The method requires only measuring the absorbance of sample solution at the selected wavelength followed by simple calculations. Hence, it was further employed for our study. 
Table 3. Efavirenz estimation in bulk by proposed method.

\begin{tabular}{cccc}
\hline S.No & $\begin{array}{c}\text { Efavirenz taken } \\
\mu \mathrm{g} / \mathrm{mL}\end{array}$ & Efavirenz found $(\mathrm{CV})$ & $\begin{array}{c}\text { \% of efavirenz } \\
\text { found(CV) }\end{array}$ \\
\hline 1 & 10 & $9.85(0.935)$ & $98.5(0.76)$ \\
2 & 20 & $19.87(0.884)$ & $99.4(0.85)$ \\
3 & 40 & $39.56(0.845)$ & $98.9(1.12)$ \\
4 & 50 & $49.55(0.765)$ & $99.1(0.99)$ \\
5 & 100 & $98.95(0.928)$ & $98.9(0.10)$ \\
\hline
\end{tabular}

Table 4. Efavirenz estimation in dosage form by developed method.

\begin{tabular}{ccccc}
\hline $\begin{array}{c}\text { Tablet } \\
\text { sample }\end{array}$ & $\begin{array}{c}\text { Label Claim, } \\
\mathrm{mg} / \text { tablet }\end{array}$ & $\begin{array}{c}\text { Actual content } \\
\text { found, mg } \pm \text { S.D }\end{array}$ & $\begin{array}{c}\text { Percent Actual } \\
\text { content found, } \pm \text { S.D }\end{array}$ & CV \\
\hline $\begin{array}{c}\text { Sample-1 } \\
\text { Efavirenz }\end{array}$ & 100 & $98.89 \pm 0.153$ & $98.89 \pm 0.153$ & 0.959 \\
$\begin{array}{c}\text { Tab.(Generic) } \\
\text { Sample-2 }\end{array}$ & & & & \\
$\begin{array}{c}\text { Efavirenz } \\
\text { Tab.(Generic) }\end{array}$ & 600 & $590 \pm 2.04$ & $98.33 \pm 0.74$ & 0.679 \\
\hline
\end{tabular}

Table 5. Efavirenz estimation in dosage form in recovery studies by proposed method.

\begin{tabular}{lcccc}
\hline \multicolumn{1}{c}{$\begin{array}{c}\text { Tablet } \\
\text { sample }\end{array}$} & $\begin{array}{c}\text { Concentration of added } \\
\text { amount of drug in the final } \\
\text { dilution, } \mu \mathrm{g} / \mathrm{mL} \pm \text { S.D }\end{array}$ & $\begin{array}{c}\text { Recovery, } \\
\mu \mathrm{g} / \mathrm{mL} \pm \mathrm{S} . \mathrm{D}\end{array}$ & $\begin{array}{c}\text { Percent } \\
\text { recovery, } \pm \text { S.D }\end{array}$ & $\mathrm{CV}$ \\
\hline $\begin{array}{l}\text { Sample- } \\
\begin{array}{l}\text { 1Efavirenz } \\
\text { Tab.(Generic) }\end{array}\end{array}$ & 10 & $9.85 \pm 0.0123$ & $98.5 \pm 0.989$ & 0.959 \\
$\begin{array}{l}\text { Sample- } \\
\begin{array}{l}\text { 2Efavirenz } \\
\text { Tab.(Generic) }\end{array}\end{array}$ & 10 & $9.89 \pm 0.0142$ & $98.9 \pm 0.975$ & 0.958 \\
\hline
\end{tabular}

\section{Method validation}

The developed estimation method proved to be accurate (accuracy varies between 10.2$5.5 \%$ ) and precise (Intra day precisions were less than 4.5\%). The method has been validated for the range $1-5 \mu \mathrm{g} / \mathrm{mL}$ using $1 \% \mathrm{w} / \mathrm{v}$ sodium lauryl sulphate solution. The method is linear over this concentration range as indicated by the $F$-test for lack of fit. Analyte recovery was better than $90 \%$ at all points on the standard curve, Intraday precision was better than $5 \%$ $\mathrm{CV}$, while accuracy was between $98-100 \%$ of nominal over this range of the estimation.

\section{Conclusions}

The developed UV spectrophotometric method for the estimation of efavirenz was found to be simple and useful with high accuracy, precision, repeatability.Sample recoveries in all formulations using the above method was in good agreement with their respective label claim or theoretical drug content, thus suggesting the validity of the method and non interference of formulation excipients in the estimation. In the selected solvent system, drugs were stable for more than 48 hours, thus suggesting that samples need not be estimated immediately after collection. The developed method was found to be stability specific and were validated as per ICH guidelines (2005) and statistical method. 


\section{References}

1. Adkins J C and Noble S, Efavirenz Drugs, 1998, 56, 1055-1064.

2. Gazzard B G, Int J Clin Pract., 1999, 53, 60-64.

3. Arendt G, Nocker D, Von Giesen H J and Nolting T. Expert Opin Drug Saf., 2007, 6(2), 147-154.

4. Gallego L, Barreiro P, Del Rio R, Gonzalez De Requena D, Rodriguez Albarino A, Gonzalez Lahoz J and Soriano V, Clin Infect Dis., 2004, 38(3), 430-432.

5. Bregt Kappelhoff S, Hilde Rosing, Alwin D R. Huitema and Jos Beijnen H. $J$ Chromatogr B., 2003, 792(2), 353-362.

6. Geetha Ramachandran A K, Hemanth Kumar, Soumya Swaminathan, Venkatesan P, Kumaraswami V and David Greenblatt J. J Chromatogr B., 2006, 835(1-2),131-135.

7. Agnes Veldkamp I, Rolf van Heeswijk P G, Pieter L, Meenhorst, Jan Mulder W, Joep M A, Lange, Jos Beijnen H, Richard M W and Hoetelmans. J Chromatogr B: Biomed Sci Appl., 1999, 734(1), 55-61.

8. Matthews C Z, Woolf E J, Mazenko R S, Haddix Wiener H, Chavez Eng C M, Constanzer M L, Doss G A and Matuszewski B K. J Pharma Biomed Anal., 2002, 28(5), 925-934.

9. Lakshmi Sailaja, Kishore Kumar K, Ravi Kumar D V R, Mohan Kumar C, Yugandhar N M and Srinubabu G, Chromatographia, 2007, 65, 359-361.

10. Cociglio M, Hillaire Buys-D, Peyriere H and Alric R, J Chromatogr Sci., 2003, 41(2), 80-86. 


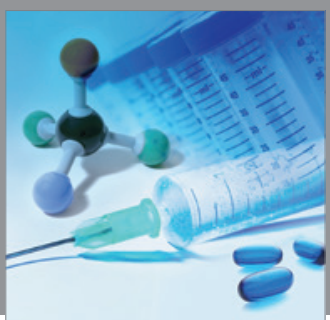

International Journal of

Medicinal Chemistry

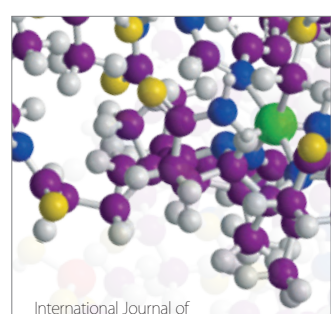

Carbohydrate Chemistry

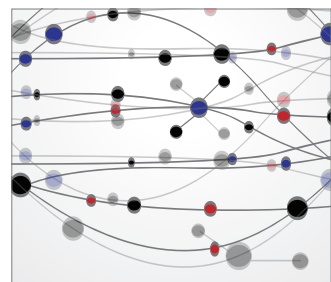

The Scientific World Journal
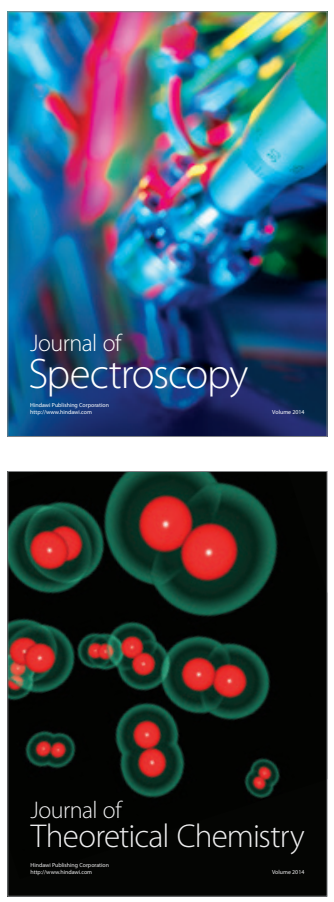
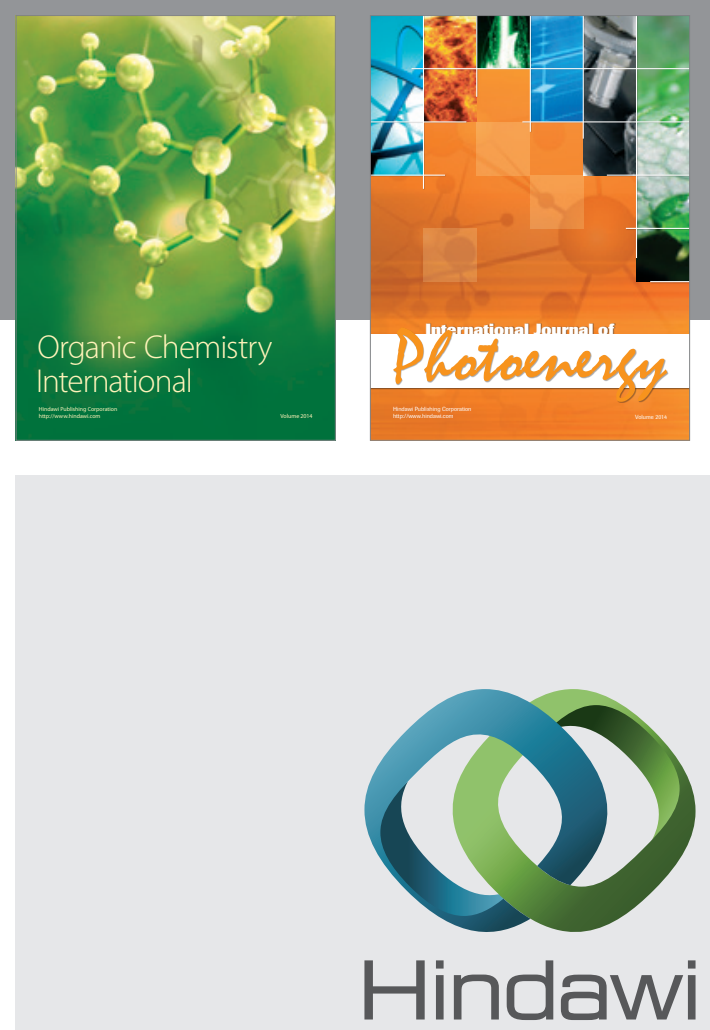

Submit your manuscripts at

http://www.hindawi.com
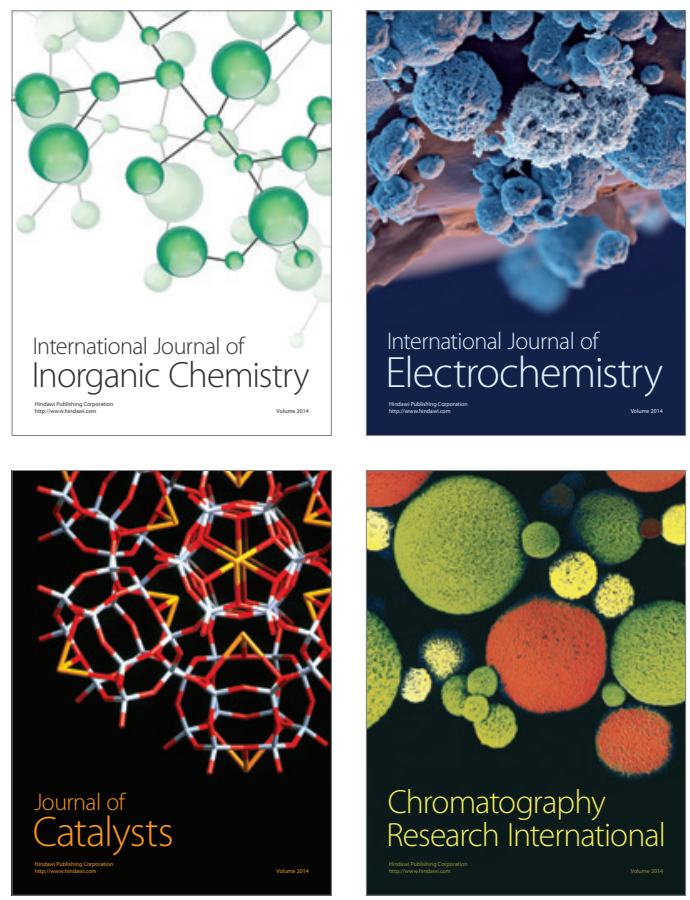
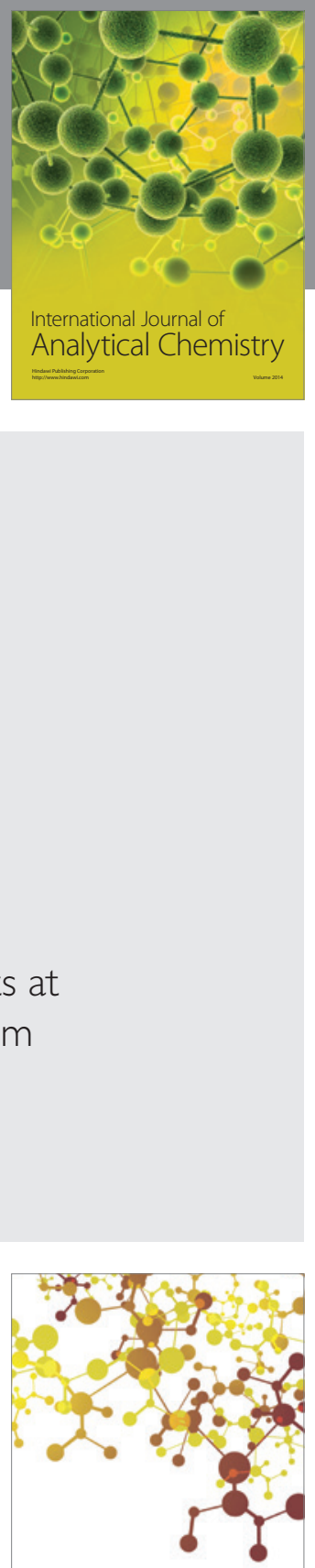

Journal of

Applied Chemistry
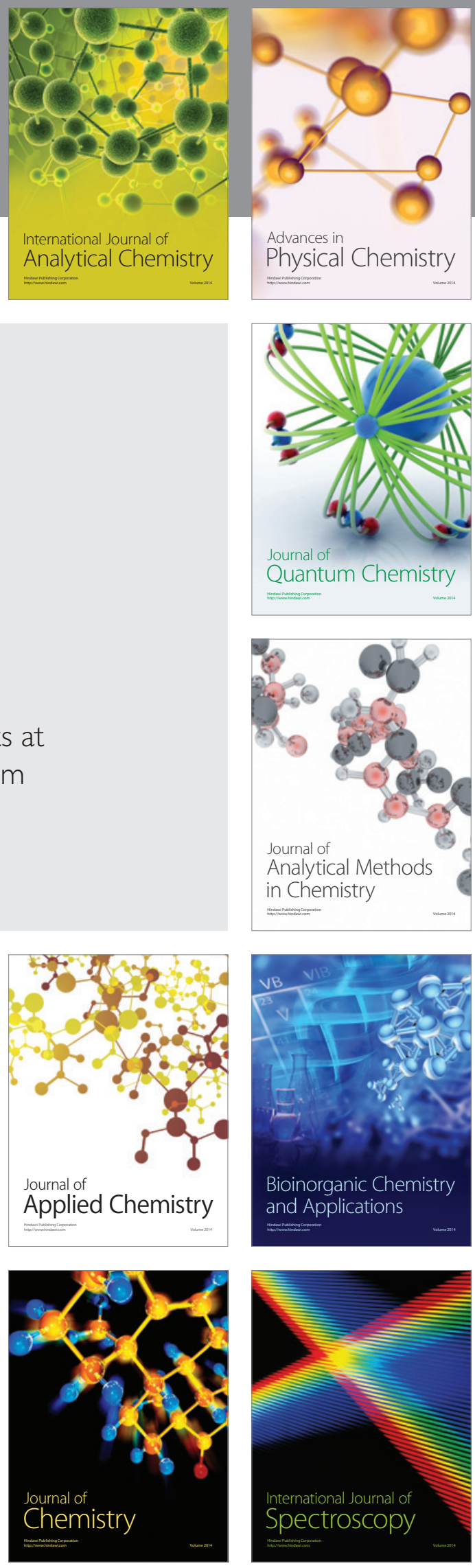